\title{
EMPLOYEE COMPETENCY AND ORGANIZATIONAL COMMITMENT TO IMPACT ORGANIZATIONAL CULTURE ON THE PERFORMANCE OF NON MEDICAL SUPPORTING EMPLOYEES AL ISLAM HOSPITAL BANDUNG
}

\author{
Rulia $^{1}$, Sri Rochani Mulyani², Farida Yuliaty ${ }^{3}$ \\ 1,2,3 Universitas Sangga Buana \\ ${ }^{1}$ korespondensi : sri.rochani@ usbypkp.ac.id
}

\begin{abstract}
ABSTRAK
This study aims to analyze the influence of Employee Competency and Organizational Commitment on Organizational Culture and their implications for Employee Performance. Determination of sample in this study using Stratified Random Sampling, and the size of 114 respondents, the analysis methode uses path analysis. The results of the study concluded that there was a significant effect simultaneously on Employee Competency and Organizational Commitment on Organizational Culture. There is partial effect Employee Competency and Organizational Commitment on Organizational Culture. The study concluded that there was a significant effect simultaneously on Employee Competency and Organizational Commitment on Employee Performance. There is partial effect Employee Competency and Organizational Commitment on Employee Performance. There are positif and significant influences Job Satisfaction on Employee Performance.
\end{abstract}

Keyword: Employee Competency, Organizational Commitment, Organizational Culture, Employee Performance

\section{INTRODUCTION}

Health is one of the basic human needs that is fundamental to a person's productivity in carrying out his daily life and the hospital is a health service institution consisting of a group of people, both medical and non-medical workers who work together to achieve a goal. To achieve this success or goal, it is necessary to have management. Good management will facilitate the organization in realizing its goals. Humans are one of the dimensions in the organization. Organizational performance is highly dependent on the performance of the individuals in it. All the work in the company, the employees are the ones who determine its success. So that various efforts to increase company productivity must start from improving employee productivity [1]. Human resources are an important asset for an organization because in essence human resources are the driving force for every activity that takes place within the organization. This is supported by [2] saying that humans have an active role in every organizational activity, namely as "planners, actors and determinants of the realization of organizational goals, thus making humans as company assets that must be maintained and their efficiency and productivity improved".

The hospital is a unique and complex organization because it is a labor-intensive institution, has special characteristics and characteristics and functions in the process of producing health services through a promotive, preventive, curative and rehabilitative health care approach. This health service must be carried out thoroughly as stated in the RI Law Number 36 of 2009 
concerning health which states that health is a human right and one of the elements of welfare that must be realized in accordance with the ideals of the Indonesian nation as stated in Pancasila and the 1945 Constitution of the Republic of Indonesia. so that the government must strive for the health sector as well as possible, namely providing adequate and accessible health services to the community.

Hospitals have various professional groups in carrying out services to the community. Based on this, hospitals have a responsibility to provide quality services according to standards to meet the needs of consumers or health service users. In order to provide quality services according to standards, hospitals also need good management, because without a clear management concept, hospital development will run slowly.

Given the internal dynamics (role development) and growing external demands, hospitals are faced with adaptation efforts to respond to external dynamics and the function of integrating internal potentials in carrying out increasingly complex tasks. Internal dynamics and external demands cause hospitals in carrying out their functions as providers of public health services to be able to overcome existing problems.

Hospital organizations have characteristics that are not shared by other organizations in general, namely most of their staff are professionals, their human resources are of various educational backgrounds, the workload is difficult to regulate, the number and nature of the work is very diverse and the output is difficult to standardize. On the other hand, human resources today are not only seen as mere resources where in the latest developments human resources are seen as more in the form of capital or assets for organizations with the term Human Capital which is not only seen as a main asset, but an asset that is valuable and can be multiplied. Developed and is also not considered a liability.

The phenomenon that is often faced by hospitals in order to achieve success is the problem between human resources and the organization, which is related to the demands of both the organization and human resources itself, including employees as part of the human resources who work in hospitals. Good human resource performance is expected to increase employee productivity as partners for medical personnel in providing services to hospital patients. The role of employees is very important because employees are part of the hospital staff who work together in providing services to patients. Employees who have the ability and skills are expected to provide the best service, so that patients feel satisfied.

Al Islam Hospital Bandung is a type B private hospital which was founded in 1990 by the West Java Islamic Women's Cooperation Agency. Located in the East Bandung area, precisely on Jalan Soekarno Hatta No. 664 Bandung. Al Islam Hospital organizes outpatient services, inpatient services, emergency services, other medical support services such as radiology and laboratories as 
well as other non-medical services to be able to provide optimal services to its customers.

The phenomenon in Al Islam Hospital that is currently happening in the face of the globalization era, namely, the hospital is experiencing slow development, as seen from the market segment that dominates the lower middle class and the perceived performance of employees is still not optimal.

The hospital where employees work is an environment that is an extrinsic motivational factor that affects employee performance, therefore hospitals need to try to maintain and maintain employee performance with programs and activities that are expected to affect performance including through socialization activities and actualization of organizational culture. Competence, commitment and organizational culture are 3 things among other things that can be done to be able to motivate extrinsically to the performance of employees in hospitals, both doctors, nurses, medical support personnel, and non-medical support personnel.

To be able to realize the company's goals in implementing the concept of quality and professional performance management, it is necessary to understand what the overall and specific objectives of performance management are. Then [3] states that the overarching goal of performance management is to foster a culture in which individuals and groups are responsible for the continued improvement of business processes and the enhancement of their own skills and contributions. This means that improving performance management not only affects the company's results, but is also able to be an added value for employees.

The second environmental factor as extrinsic motivation that affects performance is organizational culture. Culture describes a very broad and general sense, the essence of which is a pattern of behavior, beliefs, groups and all thoughts that characterize a shared value and tend to persist even though the members of the group have changed. Culture when associated with the organization, it will provide a different understanding, where organizational culture is a translation of organizational culture which can be interpreted with various meanings [4].

For the purposes of further research in this study, the authors formulate the problem, namely 1 . How is employee competence, organizational commitment, organizational culture, and employee performance at $\mathrm{Al}$ Islam Hospital Bandung, 2. How is the influence of employee competence, organizational commitment to organizational culture in general. simultaneously at Al Islam Hospital Bandung, 3. How is the influence of employee competence on organizational culture partially at $\mathrm{Al}$ Islam Hospital Bandung, 4. How is the effect of organizational commitment on organizational culture partially at RS. Al Islam Bandung, 5. How is the influence of employee competence, organizational commitment on employee performance simultaneously at $\mathrm{Al}$ Islam Hospital Bandung, 6. How is the influence of employee competence on employee performance partially at Al Islam Hospital Bandung, 7. How is the influence of 
organizational commitment on performance partially partial RS. Al Islam Bandung, 8. How is the influence of organizational culture on employee performance at $\mathrm{Al}$ Islam Hospital Bandung.

\section{LITERATURE REVIEW}

\section{Employee Competence}

Organizational culture is a system adopted by all members of the organization that distinguishes one organization from another. Organizational culture is the basis for orientation for employees to pay attention to the interests of all employees [5].

\section{Organizational Commitment}

Organizational commitment as a condition where employees believe and are willing to accept the goals of the organization and will stay or will not leave the organization [5].

\section{Organizational culture}

Organizational culture is growing in line with the increasing dynamics of the climate within the organization [6].

\section{Employee performance}

Performance is the result of work in quantity and quality achieved by an employee in carrying out tasks in accordance with the responsibilities given to him [5].

\section{METHODOLOGY}

The research used in this study is a quantitative research approach. Quantitative research approach is called the traditional method because this method has been used for a long time so that it has become a tradition as a method for research [5]. The quantitative method is a scientific/scientific method because it has fulfilled concrete/empirical, objective, measurable, rational and systematic scientific principles. Quantitative research can be defined as a research method based on positivism, used to examine certain populations or samples, data collection using research instruments, quantitative/statistical data analysis with the aim of testing predetermined hypotheses.

In accordance with the objectives to be achieved in this study, this research uses descriptive and verification methods. Descriptive method research because in this study aims to obtain a description of an object, namely the characteristics of the employee's competence, organizational commitment, organizational culture in non-medical employees, which includes changes in job performance. This research is a verification method because it is carried out to examine the effect of competence, commitment to organizational culture and its impact on nurse performance through hypothesis testing based on data obtained in the field.

The population in this study were employees of non-medical support services at Al Islam Hospital Bandung, which included: Pharmacy, Nutrition, Linen and Sterilization with a total number of 159 employees, so based on calculations, the sample in this study amounted to 114 people. 


\section{RESULTS AND DISCUSSION}

Descriptive Analysis

Responses to Employee Competence (X1), Organizational Commitment (X2), Organizational Culture (Y) and Employee

\section{Performance (Z)}

Ideally, the expected score for respondents' answers to 14 statements is 7980 . From the calculations in the table it shows the value obtained is 5456 or $68.4 \%$ of the ideal score of 7980. Thus the competence is in the strong category. Organizational Commitment (X2) with 14 statements. The following is a recap of the results of the calculation of respondents' responses to organizational commitment (X2). Ideally, the expected score for respondents' answers to 14 statements is 7980 . From the calculations in the table it shows the value obtained is 5701 or $71.4 \%$ of the ideal score of 7980. Thus, commitment is in the good category. Organizational Culture (Y) with 15 statements. The following is a recap of the results of the calculation of respondents' responses to Organizational Culture (Y). Ideally, the expected score for respondents' answers to 15 statements is 8550 . From the calculations in the table it shows the value obtained is 5850 or $68.4 \%$ of the ideal score of 8550 . Thus, organizational culture is in the category. Employee Performance (Z) with 17 statements. The following is a recap of the results of the calculation of respondents' responses to Employee Performance (Z).

Ideally, the expected score for respondents' answers to 17 statements is 9690 . From the calculations in the table it shows the value obtained is 6696 or $69.1 \%$ of the ideal score of 9690 . Thus, employee performance is in the good category.

\section{Verification Analysis}

\section{Path Analysis}

Path analysis was conducted to determine the effect of employee competence and organizational commitment on organizational culture and the influence of organizational culture on employee performance, before conducting path analysis the data was first transformed from ordinal data to intervals. The picture of the complete path analysis can be seen in Figure 1.

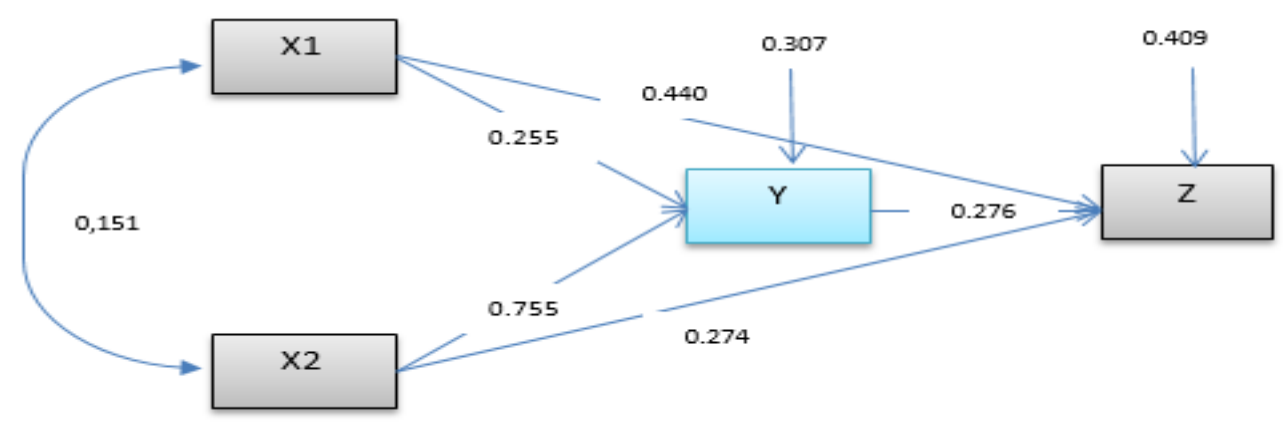

Figure 1: Complete Path Chart 
Substructure Path Analysis 1The Influence of Employee Competence (X1) and Organizational Commitment (X2) on Organizational Culture (Y)

Table 1: Line Coefficient Quantity

\begin{tabular}{|c|c|c|c|}
\hline Variable & Path Analysis & $\begin{array}{c}\text { Simultaneous } \\
\text { Influence }\end{array}$ & Residue Effect \\
\hline Employee competence $(\mathrm{X} 1)$ & $\mathrm{P}_{\mathrm{yx} 1}=0,255$ & 0.693 & 0.307 \\
\cline { 1 - 2 } $\begin{array}{c}\text { Organizational commitment } \\
(\mathrm{X} 2)\end{array}$ & $\mathrm{Pyx} 2=0,755$ & 0.303 \\
\hline
\end{tabular}

By paying attention to the table above, the following path equation is obtained:

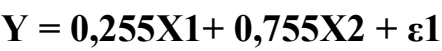

(1)

The value of the path coefficient of the employee competence variable is smaller than the path coefficient of the organizational commitment variable, meaning that organizational commitment is more decisive (greater influence) on organizational culture than employee competence, either directly or indirectly.

From the table, the total influence of employee competence and organizational commitment variables on organizational culture is 0.693 or about $69.3 \%$, while the influence of other factors on organizational culture is indicated by a value of 0.307 or about $30.7 \%$. In other words, the organizational culture variable can be explained as being influenced by $69.3 \%$ by the employee competence and organizational commitment variables. The remaining $30.7 \%$ of the organizational culture variables can be explained as being influenced by other variables not examined. The following is a picture of the influence between employee competence and organizational commitment to organizational culture.

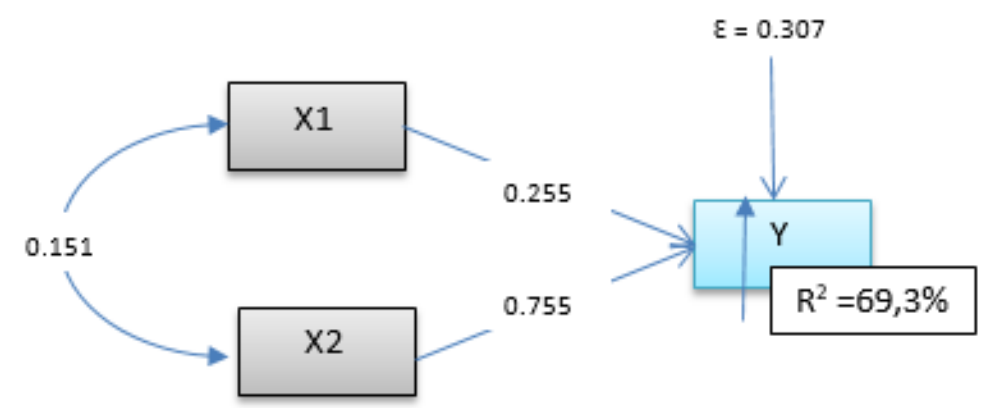

Figure 2: The Effect of Employee Competence and Organizational Commitment on Organizational Culture

\section{Hypothesis test}

\section{Simultaneous Path Coefficient Test}

He main hypothesis of this research is that

Employee Competence (X1) and

Organizational Commitment (X2) affect

Organizational Culture (Y). The research hypothesis is stated in the following statistical hypothesis:

$\mathrm{H} 0: \rho_{y x 1}=\rho_{y x 2}=0$

H1: There is at least one $P_{y x i} \neq 0, \mathrm{i}=1$ dan 2

The test statistics used are: 


$$
F=\frac{(n-k-1) \sum_{i=1}^{k} p_{y x i} r_{y x i}}{k\left(1-\sum_{i=1}^{k} p_{y x i} r_{y x i}\right)} \ldots \ldots \ldots \ldots \ldots \ldots \ldots \ldots \ldots \ldots
$$

(2)

Table 2: Simultaneous Testing

\begin{tabular}{|c|c|c|c|c|c|}
\hline Alternative Hypothesis & F count & db & F table & Decision & Conclusion \\
\hline $\begin{array}{c}\mathrm{X} 1 \text { and } \mathrm{X} 2 \\
\text { simultaneously affect } \mathrm{Y}\end{array}$ & 125.522 & $\mathrm{db}_{1}=2$ & \multirow{2}{*}{3.078} & $\mathrm{H}_{0}$ rejected & Significant \\
\cline { 3 - 3 } & $\mathrm{db}_{2}=111$ & & & \\
\hline
\end{tabular}

In the table above, we can see that the test results show the calculated $\mathrm{F}$ value (125.522) $>$ Ftable (3.078), meaning that employee competence (X1) and organizational

\section{Partial Path Coefficient Test}

Because the overall test results give significant results, then to find out which independent variables partially have a significant effect on Organizational Culture (Y) can be continued with partial testing.

In order to partially test the path coefficient, the hypothesis formulation is first determined as follows:

$H_{0}: \rho_{y x_{i}}=0$ There is no significant effect of employee competence on organizational culture
Test criteria, Reject Ho if F count $\geq F$ table, accept Ho in other cases. Where F table is obtained from the distribution table $\mathrm{F}$ with $=$ $5 \%$ and degrees of freedom $\mathrm{db} 1=\mathrm{k}$, and $\mathrm{db} 2$ $=\mathrm{n}-\mathrm{k}-1$ commitment (X2) simultaneously have a significant influence on organizational culture (Y).

$H_{1}: \rho_{y x_{i}} \neq 0$ There is a significant influence of employee competence on organizational culture.

The test statistics used are:

$$
t_{i}=\frac{\rho_{y x i}}{\sqrt{\frac{\left(1-R^{2}\right) C R_{i i}}{n-k-1}}} \quad \mathrm{i}=1 \text { dan } 2
$$

Test Criteria:

Reject Ho if $\mathrm{t}$ count $>\mathrm{t}$ table $\left(t_{\alpha ; n-k-1}\right)$

The calculation results can be seen in the following table:

Table 3: Partial Test

\begin{tabular}{|c|c|c|c|c|c|}
\hline Hypothesis & $\mathbf{t}$ count & $\mathbf{d b}$ & $\mathbf{t}$ table & Decision & Conclusion \\
\hline $\mathrm{Pyx}_{1}=0$ & 4.804 & 111 & 1.982 & Ho rejected & Significant \\
\hline $\mathrm{Pyx}_{2}=0$ & 14.197 & 111 & 1.982 & Ho rejected & Significant \\
\hline
\end{tabular}

From the table above, we can see that the $\mathrm{t}$ value for each variable of employee competence (X1) and organizational commitment (X2) is greater than the value of $\mathrm{t}$ table, which means that employee competence (X1) and organizational commitment (X2) partially provide significant influence on organizational culture (Y). 
Table 4: Direct and Indirect Effects of Employee Competence (X1) and Organizational Commitment (X2) on Organizational Culture (Y)

\begin{tabular}{|c|c|c|c|c|c|}
\hline \multirow[t]{2}{*}{ Connection } & \multirow{2}{*}{$\begin{array}{c}\text { Path } \\
\text { Coefficient }\end{array}$} & \multirow{2}{*}{$\begin{array}{c}\text { Direct } \\
\text { Influence }\end{array}$} & \multicolumn{2}{|c|}{$\begin{array}{c}\text { Indirect Influence } \\
\text { through }\end{array}$} & \multirow{2}{*}{$\begin{array}{c}\text { Total } \\
\text { Effect on } \\
\text { Y }\end{array}$} \\
\hline & & & X1 & $\mathbf{X} 2$ & \\
\hline $\begin{array}{c}\text { Employee competence } \\
\text { (X1) }\end{array}$ & 0.255 & 0.065 & & 0.029 & 0.094 \\
\hline $\begin{array}{c}\text { Organizational } \\
\text { Commitment (X2) }\end{array}$ & 0.755 & 0.570 & 0.029 & & 0.599 \\
\hline \multicolumn{5}{|c|}{ Pengaruh Total } & 0.693 \\
\hline
\end{tabular}

Based on the table above:

1. The direct effect of employee competence (X1) on organizational culture (Y) is 0.065 ; the indirect effect of employee competence (X1) on organizational culture (Y) through organizational commitment (X2) is 0.029 ; so that the total influence of employee competence (X1) on organizational culture (Y) through organizational commitment (X2) is 0.094 .

2. The direct effect of organizational commitment (X2) on organizational culture (Y) is 0.570 ; the indirect effect of organizational commitment (X2) on organizational culture (Y) through employee competence (X1) is 0.029 ; so that the total influence of employee competence (X2) on organizational culture (Y) through employee competence (X1) is 0.599 .

3. The effect of total employee competence (X1) and organizational commitment (X2) on organizational culture $(\mathrm{Y})$, is 0.69 .3 or $69.3 \%$.

\section{Substructure Path Analysis 2}

The Effect of Employee Competence (X1) and Organizational Commitment (X2) on Employee Performance $(Z)$

Table 5: Line Coefficient Quantity

\begin{tabular}{|c|c|c|c|}
\hline Variable & Path Coefficient & $\begin{array}{c}\text { Simultaneous } \\
\text { Influence }\end{array}$ & $\begin{array}{c}\text { Residue } \\
\text { Effect }\end{array}$ \\
\hline Kompetensi Karyawan (X1) & $\mathrm{P}_{\mathrm{yx} 1}=0,440$ & & \\
\cline { 1 - 2 } Komitmen Organisasi (X2) & $\mathrm{Pyx} 2=0,274$ & 0.591 & 0.409 \\
\cline { 2 - 2 } & & & \\
\hline
\end{tabular}

By paying attention to the table above, the following path equation is obtained:

$\mathrm{Z}=0,440 \mathrm{X} 1+0,274 \mathrm{X} 2+0,276 \mathrm{Y}+\varepsilon 1 \ldots \ldots$

The value of the path coefficient of the employee competence variable is greater than the path coefficient of the organizational commitment and organizational culture variable, meaning that employee competence is more decisive (greater influence) on employee performance than organizational commitment and organizational culture, either directly or indirectly.

From the table, the total influence of employee competence, organizational commitment and organizational culture variables on employee performance is 0.591 or about $59.1 \%$, while the influence of other 
factors on employee performance is indicated by a value of 0.409 or about $40.9 \%$. In other words, the variable of employee performance can be explained by $59.1 \%$ by the variables of employee competence, organizational commitment and organizational culture. The remaining $40.9 \%$ of employee performance variables can be explained by other variables not examined.

The following is a picture of the effect of employee competence and organizational commitment on employee performance.
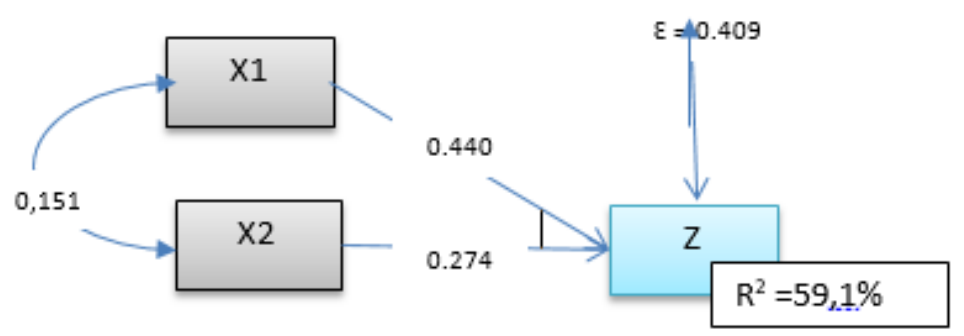

Figure 3: The Effect of Employee Competence and Organizational Commitment on Employee Performance

\section{Hypothesis test}

\section{Simultaneous Path Coefficient Test}

The main hypothesis of this study is that employee competence (X1), organizational commitment (X2) and organizational culture (Y) affect employee performance (Z). The research hypothesis is stated in the following statistical hypothesis:

$\mathrm{H} 0: \rho_{y x 1}=\rho_{y x 2}=0$

H1 : There is at least one $P_{y x i} \neq 0, \mathrm{i}=1$ dan 2
The test statistics used are:

$$
F=\frac{(n-k-1) \sum_{i=1}^{k} p_{y x i} r_{y x i}}{k\left(1-\sum_{i=1}^{k} p_{y x i} r_{y x i}\right)} \ldots \ldots \ldots \ldots \ldots \ldots \ldots
$$

Test criteria, Reject Ho if $\mathrm{F}$ count $\geq \mathrm{F}$ table, accept Ho in other cases. Where F table is obtained from the distribution table $\mathrm{F}$ with $=$ $5 \%$ and degrees of freedom $\mathrm{db} 1=\mathrm{k}$, dan $\mathrm{db} 2$ $=\mathrm{n}-\mathrm{k}-1$

Table 6: Simultaneous Testing

\begin{tabular}{|c|c|c|c|c|c|}
\hline Alternative Hypothesis & F count & db & F table & Decision & Conclusion \\
\hline \multirow{2}{*}{$\begin{array}{l}\text { Kompeten si karyawan } \\
\text { (X1), Komitmen } \\
\text { organisasi (X2) secara } \\
\text { simultan berpengaruh } \\
\text { terhadap Kinerja } \\
\text { karyawan }(\mathrm{Z})\end{array}$} & \multirow[b]{2}{*}{53.056} & $\mathrm{db}_{1}=3$ & \multirow[b]{2}{*}{2.687} & \multirow[b]{2}{*}{$\mathrm{H}_{0}$ rejected } & \multirow[b]{2}{*}{ Significant } \\
\hline & & $\mathrm{db}_{2}=110$ & & & \\
\hline
\end{tabular}

In the table above, we can see that the test results show the value of Fcount (53.056) > Ftable (2.678), meaning that employee competence (X1), organizational commitment (X2) simultaneously have a significant effect on employee performance (Z).

\section{Partial Path Coefficient Test}

Because the overall test results provide significant results, to find out which independent variables partially have a significant effect on employee performance (Z) can be continued with partial testing. In order to partially test the path coefficient, the 
hypothesis formulation is first determined as follows:

$H_{0}: \rho_{y x_{i}}=0$

There is no significant effect

of employee competence on employee performance.

$H_{1}: \rho_{y x_{i}} \neq 0$

There is a significant influence of employee competence on employee performance.

$H_{0}: \rho_{y x_{i}}=0 \quad$ There is no significant effect of organizational commitment on employee performance.
$H_{1}: \rho_{y x_{i}} \neq 0$ There is a significant effect of organizational commitment on employee performance.

The test statistics used are:

$$
t_{i}=\frac{\rho_{y x i}}{\sqrt{\frac{\left(1-R^{2}\right) C R_{i i}}{n-k-1}} \quad \mathrm{i}=1 \text { and } 2}
$$

Test Criteria:

Reject Ho if $\mathrm{t}$ count $>\mathrm{t}$ table $\left({ }^{t_{\alpha ; n-k-1}}\right)$ The calculation results can be seen in the following table:

Table 7: Partial Test

\begin{tabular}{|c|c|c|c|c|c|}
\hline Hypothesis & $\mathbf{t}$ count & $\mathbf{d b}$ & $\mathbf{t}$ table & Decision & Conclusion \\
\hline $\mathrm{Pzx}_{1}=0$ & 6.488 & 110 & 1.982 & $\mathrm{H}_{0}$ rejected & Significant \\
\hline $\mathrm{Pzx}_{2}=0$ & 2.648 & 110 & 1.982 & $\mathrm{H}_{0}$ rejected & Significant \\
\hline
\end{tabular}

From the table above, we can see that the $\mathrm{t}$ value for each variable of employee competence (X1) and organizational commitment $(\mathrm{X} 2)$ is greater than the value of t table, which means that employee competence (X1) and organizational commitment (X2) partially provide significant influence on employee performance $(\mathrm{Z})$.

The Effect of Employee Competence (X1), Organizational Commitment (X2) on Employee Performance $(Z)$

Table 8: The Effect of Employee Competence (X1), Organizational Commitment (X2) on Employee Performance (Z)

\begin{tabular}{|c|c|c|c|c|c|}
\hline \multirow{2}{*}{ Connection } & $\begin{array}{c}\text { Path } \\
\text { Coefficient }\end{array}$ & $\begin{array}{c}\text { Direct } \\
\text { Influence }\end{array}$ & \multicolumn{2}{|c|}{$\begin{array}{c}\text { Indirect Influence } \\
\text { through }\end{array}$} & $\begin{array}{c}\text { Total Influence on } \\
\text { Employee Performance } \\
\text { (Z) }\end{array}$ \\
\cline { 3 - 5 } & 0.440 & 0.194 & $\mathbf{X 1}$ & $\mathbf{X 2}$ & 0.212 \\
\hline $\begin{array}{c}\text { Employee } \\
\text { competence } \\
(\mathrm{X} 1)\end{array}$ & 0.274 & 0.075 & 0.018 & & 0.093 \\
\hline $\begin{array}{c}\text { Organizational } \\
\text { Commitment } \\
(\mathrm{X} 2)\end{array}$ & \multicolumn{2}{|c|}{ Total Effect of X1, X2 on Z } & 0.305 \\
\hline \multicolumn{2}{|c|}{} \\
\hline
\end{tabular}

Based on the table above:

1. The direct effect of employee competence (X1) on employee performance (Z) is 0.194; the indirect effect of employee competence
(X1) on employee performance (Z) through organizational commitment (X2) is 0.018; so that the total influence of employee competence $(\mathrm{X} 1)$ on employee performance 
(Z) through organizational commitment (X2) is 0.212 .

2. The direct effect of organizational commitment (X2) on employee performance (Z) is 0.075 ; the indirect effect of organizational commitment (X2) on employee performance $(Z)$ through employee competence (X1) is 0.018 ; so that the total influence of organizational commitment (X2) on employee performance ( $\mathrm{Z}$ ) through employee competence (X1) is 0.093 .

Substructure Path Analysis 3Substructure 3 explains the influence of organizational culture (Y) on employee performance $(Z)$.

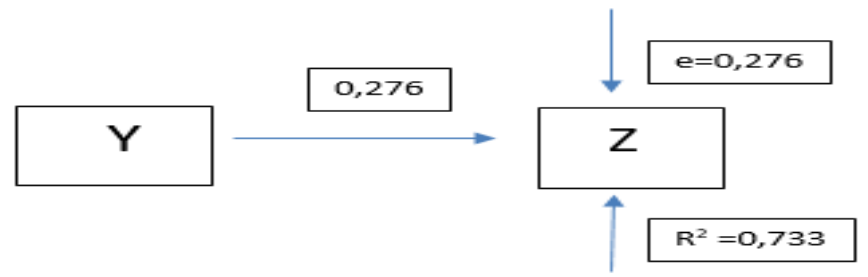

Figure 4: The Influence of Organizational Culture (Y) on Employee Performance (Z)

From Figure 4 it can be explained:

a. The value of the path coefficient of organizational culture on employee performance is 0.276 .

b. Employee performance (Z) is influenced by organizational culture $(\mathrm{Y})$ by $73.3 \%$, with a residual value of $27.6 \%$. This means that employee performance is influenced by variables that are not used as models in the study by $27.6 \%$.

\section{CONCLUSION}

Based on the analysis of secondary data and primary data as well as the results of path analysis and hypothesis testing from research data on employees of non-medical support fields at Al Islam Hospital Bandung, it can be concluded as follows:

1. The condition of employee competence, organizational

commitment, organizational culture and employee performance.

1.1 The competence of employees is in the criteria of moderate to strong, meaning that the competence of employees at $\mathrm{Al}$ Islam Hospital Bandung has been going well. Employee competence is formed by four dimensions, namely Technical HR skills, (Technical Resource Skills), Strategic skills (Strategic Skills), Organizational/management skills (Organizational Skills) and Personal skills (Personal Skills).

1.2 The condition of organizational commitment is in the criteria of moderate to strong, meaning that the organizational commitment at $\mathrm{Al}$ Islam Hospital Bandung has been going well. Organizational 
commitment is formed by three dimensions, namely affective commitment, continuance commitment and normative commitment.

1.3 The condition of the employee's organizational culture is in the criteria of moderate to strong, meaning that the organizational culture at $\mathrm{Al}$ Islam Hospital Bandung has been carried out well. Organizational culture is formed by five dimensions, namely: the work itself, the suitability between work and personality, colleagues, supervisors and superiors, and the work environment.

1.4 The condition of employee performance is in the criteria of moderate to strong, meaning that the performance of Al Islam Hospital employees has been going well. Employee performance is formed by four dimensions, namely: Employee Discipline Level, Employee Ability Level, Innovative and Spontaneous Behaviors..

2. Employee competence and organizational commitment simultaneously affect organizational culture. If these two variables are carried out well together, the organizational culture will increase.

3. Employee competence has a positive and significant effect on organizational culture, meaning that the better the employee's competence, the more organizational culture will increase. Employee competencies are formed by four, the order of the largest dimensions to the order of the lowest dimensions such as: personal skills (personal skills), interpersonal skills, organizational/management skills (Organizational Skills, Technical HR skills, (technical resource skills), and the smallest dimension strategic skills (strategic skill).

4. Organizational commitment has a positive and significant effect on organizational culture, it can be interpreted that the higher the organizational commitment, the higher the organizational culture. The formation of the dominant employee commitment is formed by the largest dimension of continuance commitment, the largest average of the two dimensions of normative commitment and the lowest dimension of affective commitment. The highest dimension needs to be maintained while the lowest dimension needs to be improved, but the three dimensions must be implemented synergistically with each other so as to have an impact on organizational culture.

5. Employee competence and organizational commitment simultaneously affect employee performance, it can mean that these two variables can improve employee performance if together, the two variables are carried out well, then employee performance will increase. 
Employee competence and organizational commitment if carried out together will affect employee performance.

6. Employee competence has a positive and significant effect on employee performance, meaning that the better the employee's competence, the performance will increase. The highest dimension needs to be maintained and the lowest dimension is further improved, the three dimensions that make up employee competence need to be carried out to support each other so that it will affect the organizational culture.

7. Organizational commitment has a positive and significant effect on employee performance, it can be interpreted that the higher the organizational commitment, the higher the employee performance, the formation of the dominant employee commitment is formed by the largest dimension of continuous commitment, the largest average of the two dimensions of normative commitment and the lowest dimension of affective commitment. . The highest dimension needs to be maintained while the lowest dimension needs to be improved, but the three dimensions must be implemented synergistically with each other so as to have an impact on employee performance.

8. The influence of organizational culture has a positive and very significant effect on employee performance, organizational culture has a positive and significant effect on employee performance, it can be interpreted that if organizational culture increases, employee performance will also increase, in other words employees must be able to improve their performance through a high organizational culture, the formation of the dominant organizational culture on the dimensions of organizational culture formed five dimensions, the suitability between work with the largest dimension of personality, the work environment the second largest dimension, supervisors and superiors the third largest dimension, coworkers and the work itself the lowest dimension.

\section{REFERENCES}

[1] Biller, Panjaitan, 2017, Manajemen Sumber Daya Manusia, Bandung, Lekkas.

[2] Hasibuan, Malayu Sp. 2012. Manajemen SDM. Edisi Revisi, Cetakan Ke Tigabelas. Jakarta: Bumi Aksara.

[3] Armstrong, Michael, 2004 "Strategic Human Resources Management" A Uid To Action - 4 Th, Edition - Kogan Page, London and Philapedia.

[4] Husnan, Suad dan Enny Pudjiastuti, (2015), Dasar-Dasar Manajemen Keuangan, Edisi Ketujuh. Yogyakarta: UPP STIM YKPN.

[5] http://repository.stei.ac.id/2544/4/BAB $\% 20 I I . p d f$

[6] http://repo.darmajaya.ac.id/538/3/BAB $\% 20 I I . p d f$ 